\title{
Geochemical Characteristics and Chemical Electron Microprobe U-Pb-Th Dating of Pitchblende Mineralization from Gabal Gattar Younger Granite, North Eastern Desert, Egypt
}

\author{
Hassan A. A. Shahin \\ Nuclear Materials Authority, Cairo, Egypt \\ Email: hassanshahin744@yahoo.com
}

Received September 18, 2013; revised October 14, 2013; accepted October 21, 2013

\begin{abstract}
Copyright (c) 2014 Hassan A. A. Shahin. This is an open access article distributed under the Creative Commons Attribution License, which permits unrestricted use, distribution, and reproduction in any medium, provided the original work is properly cited. In accordance of the Creative Commons Attribution License all Copyrights (C) 2014 are reserved for SCIRP and the owner of the intellectual property Hassan A. A. Shahin. All Copyright (C) 2014 are guarded by law and by SCIRP as a guardian.
\end{abstract}

\section{ABSTRACT}

Pitchblende mineralization was studied in the younger granite samples collected from Gabal Gattar, north Eastern Desert, Egypt using electron scanning microscope (ESM) and electron probe microanalyses (EPMA). This study revealed that this pitchblende contains significant $\mathrm{Zr}$ content reaching up to $\left(66.80 \% \mathrm{ZrO}_{2}\right)$, which suggests that volcanic rocks were probably the source of such a deposit. High level emplaced high-K Calc-alkaline plutons as Qattar granite may have been associated with their volcanic equivalent emplaced in the surrounding area or now eroded. Lead content of the pitchblende mineralization is high and with moderate volcanics (up to $7.71 \% \mathrm{PbO}$ ). In contrast, it is low in $\mathrm{ThO}_{2}, \mathrm{Y}_{2} \mathrm{O}_{3}$ and $\mathrm{REE}_{2} \mathrm{O}_{3}$. High $\mathrm{Zr}$ and $\mathrm{Pb}$ content associated with pitchblende mineralization from Gattar granite indicates that the source of this mineralization derived from volcanic magma not from granitic magma. According to the calculation of U-Pb chemical ages using $\mathrm{U}$, Th and Pb content measured with an electron microprobe for this pitchblende yielded ages within 543 - 657 Ma indicating a Pan-African age for this mineralization. This is the first time that a Pan-African age (543 to $657 \mathrm{Ma}$ ) is recorded for a U-mineralization in Gabal Gattar younger granite in the north Eastern Desert, Egypt.

\section{KEYWORDS}

\section{Pitchblende Mineralization; Gabal Gattar Granite; Chemical U-Pb-Th Dating}

\section{Introduction}

Gabal Gattar area is located in the north Eastern Desert, at a distance of about $70 \mathrm{~km}$ southwest of Hurghada city between latitudes $27^{\circ} 02^{\prime} 00^{\prime \prime}-27^{\circ} 08^{\prime} 30^{\prime \prime} \mathrm{N}$ and longitudes $33^{\circ} 13^{\prime} 26^{\prime \prime}$ - 3325'47"E (Figure 1). Geomorphologically, The Qattarian batholith is nearly of oval shape, of $30 \mathrm{~km}$ long in N-S direction and about $20 \mathrm{~km}$ wide, covering an area of about $600 \mathrm{~km}^{2}$. Wadi Al Ghozah major fault of nearly $\mathrm{N} 55^{\circ} \mathrm{E}$ trend divides the batholith into northern and southern parts. The area is characterized by rough, steep slopped and ragged mountainous, where Gabal Gattar, (1963 m a.s.l.); Gabal Um Dissi (1556 m a.s.l.); Gabal Thelma (1733 m a.s.l); Gabal Abu El Hassan (1550 m a.s.l.); Gabal Abu El Hassan El Ahmar (1234 m a.s.l.) and Gabal Abu Samyuok (1750 m a.s.l.) represented high peaks in the area (Figure 2).

The area was studied geologically, mineralogically and radiometrically by numerous authors e.g. Ghobrial and Lotfi [1], Moussa and Abu El Leil [2], Stern et al. [3], El Rakaiby and Shalaby [4], Willis et al. [5], Attawiya [6], Sayyah and Attawiya [7], Salman et al. [8], El Kammar et al. [9], El Shershaby [10], El Sayed et al. [11], Raslan [12], Wasfi et al. [13] and Abdel Warith et al. [14].

Few authors studied the isochron age of Gabal Gattar younger granite, e.g. Schurmann [15] determined an age of 484 Ma for Gabal Gattar younger granites (K/Ar method), Stern and Hedge [16] gave an age of 579 Ma for the granites of Gabal Gattar, (zircon analyses), Hashad [17] 


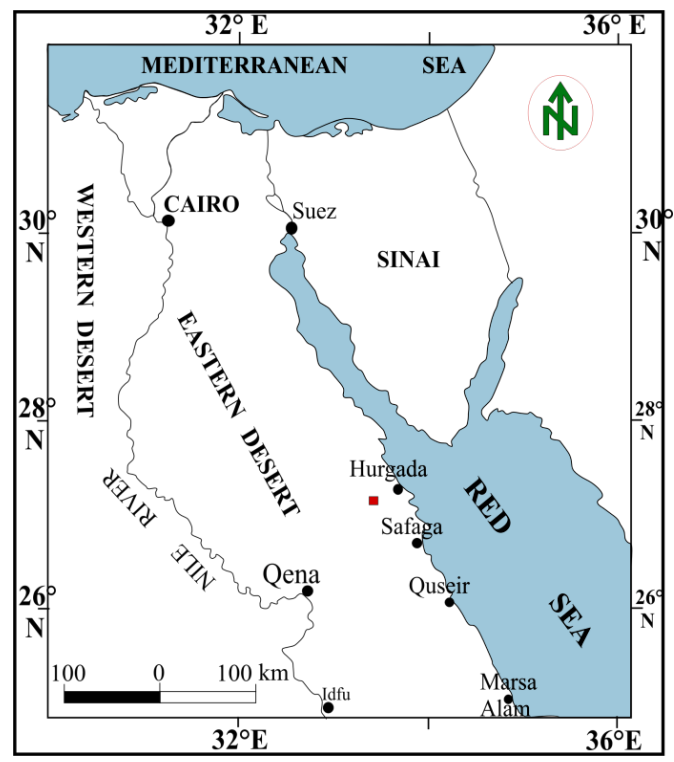

Figure 1. Location map of the studied area ( $\square$ ).

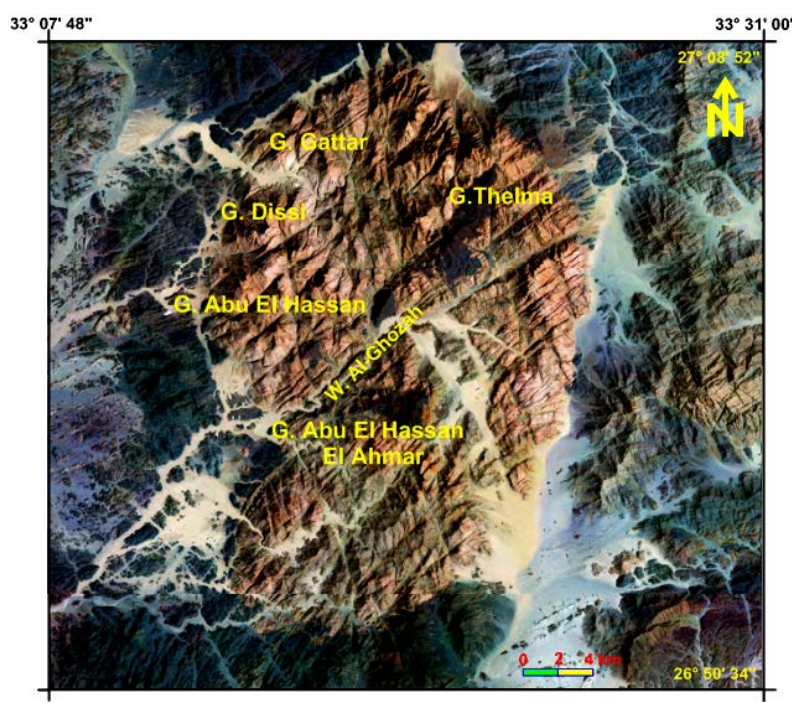

Figure 2. TMlandsat image for Gabal Gattar area.

obtained an Rb-Sr age for Gattar granites lying within 450 - $675 \mathrm{Ma}$ and Moussa [18] gave an age of $570 \mathrm{Ma}$ for Gattar granites (Rb-Sr method). The lack and scarcity of the chronological data for uranium mineralization prevent the correlation for this mineralization with others in the different areas in the Eastern Desert.

This paper focuses on petrographical, mineralogical and electron microprobe investigations of the pitchblende from Gabal Gattar younger granite.

\section{Geologic Setting}

Geology of the concerned area is focused mainly on the younger granite of Gabal Gattar. Gabal Gattar represent the northern parts of a big pink granite batholith. This granite mass occurs as mountain terrain forming mod- erate to high relief hills, ridges and multi-peaks. It is composed mainly of younger granite forming marginal sharp intrusive contacts with the surrounding countryrocks which include; metavolcanics, diorite and Hammamat sediments (Figure 3, after Rose [19]). Younger granite range in colors from pale pink to pink and sometime show reddish pink color along fault planes and shear zones. They are massive, varying in grain size from coarse-grained pegmatitic texture to fine-grained, but medium-grained is the prevailing one and show few mafic minerals. Silicification, hematitization, Kaolinization, chloritization, fluoritzation and episyentization are the most common alteration features recognized along the major faults and shear zone dissected Gattar younger granites.

Pegmatites, quartz veins and aplites dykes are the most abundance encountered at the marginal parts of this granites. Dykes show variable distribution and composition in Gattar area. They represented by two main groups, the first group acidic dykes which comprising granite porphyry and granophyres dykes, while the second group represented by intermediate dykes which include basaltic and andesitic dykes. Gabal Gattar granite is strongly jointed and fractured. The most predominate strike direction of these joints and fractures are: NE-SW, NW-SE, ENE-WSW and NNW-SSE. Dykes are mainly extending in NE-Sw, ENE-WSW and E-W. Gabal Gattar area was traversed by several strike-slip faults trending in the NE-SW, N-S, NW-SE, E-W, ENE-WSW and NNW-SSE directions. According to the field relations, faults in Gabal Gattar area can be arranged chronologically, starting with the youngest as follow, N-S, NNW-SSE, NW-SE, NE-SW and E-W directions. Uranium mineralization in Gabal Gattar younger granite is structurally controlled vein-type (Salman et al. [8]). The vein-type U-mineralization in Central Eastern Desert is mostly controlled by fractures trending NNE-SSW, ENE-WSW and NW-SE (El Shazly et al. [20] and Bakhitand Kassas [21]).

\section{Petrography of the Host Rock}

Pitchblende mineralization occurs in the younger granite of Gabal Gattar as vein-type. These younger granites are pink to reddish in color, massive and show few mafic minerals. This granite displays in some areas hematitic alteration especially in the fault zones. Microscopic studies revealed that the rock is medium to coarse-grained and essentially composed of quartz, perthite, potash feldspars with subordinate amount of plagioclase, biotite and secondary muscovite. Accessory minerals are zircon, fluorite and some apatite. Quartz occurs as subhedral to anhedral megacrysts up to $3 \times 2.5 \mathrm{~mm}$ and small crystals up to $0.1 \times 0.2 \mathrm{~mm}$. It is found in two generation, the older fills the interstices between the feldspar crystals, whereas the younger is graphically intergrowth with 


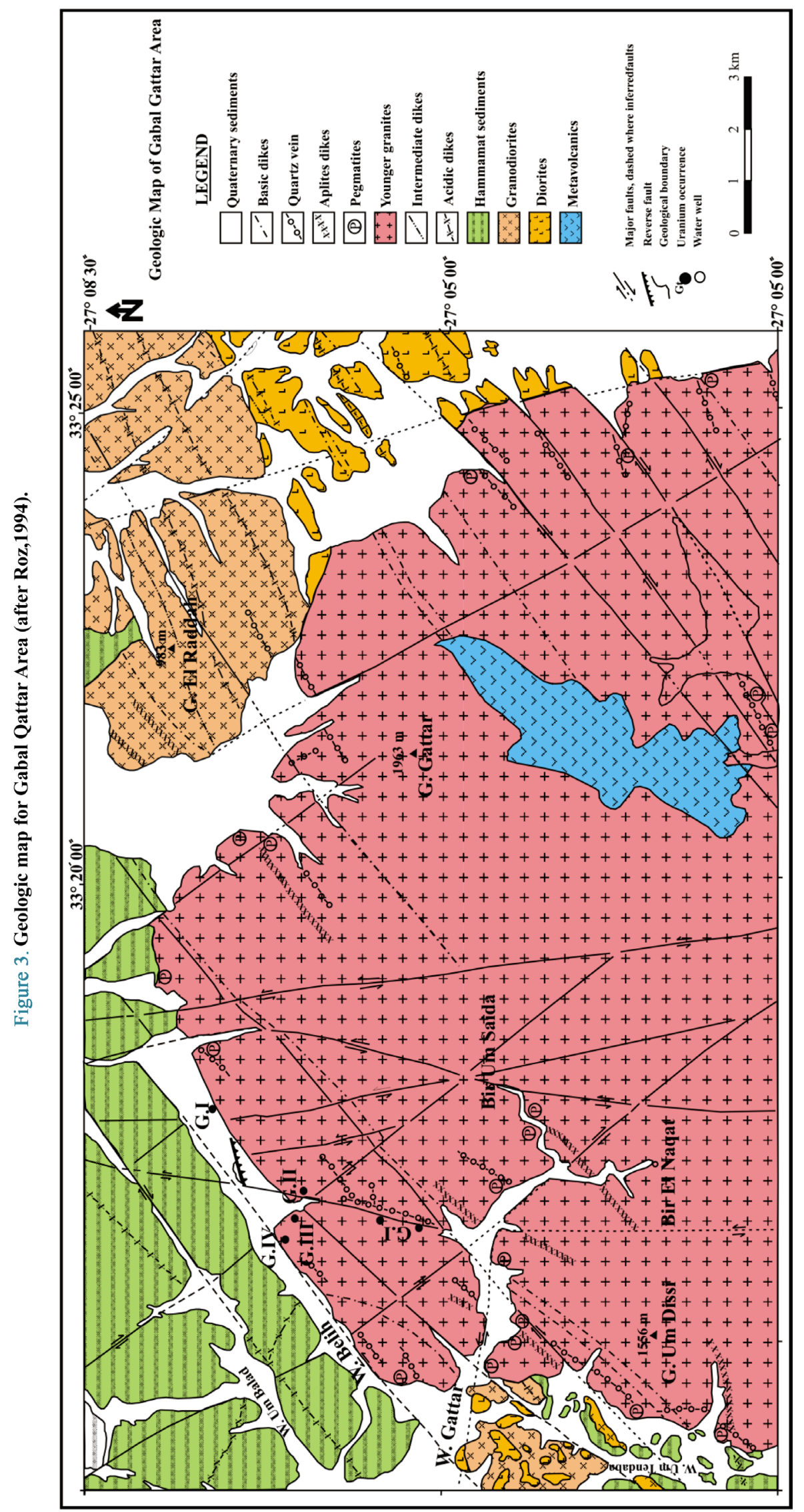


perthite crystals (Figure 4A).

Perthite occurs as subhedral megacrysts up to $2.5 \times$ $3.25 \mathrm{~mm}$. Perthitic veinlets are the most predominate type of perthite in these rocks (Figure 4A). Potash feldspare are mainly perthite with few amount of microcline and orthoclase crystals. The orthoclase occurs as anhedral to subhedral crystals reaching $2.3 \times 0.25 \mathrm{~mm}$ in size. Plagioclase represents the few constituent mineral in these rocks. It is represented by euhedral crystals up to $2.5 \times$ $2.3 \mathrm{~mm}$. These plagioclase crystals are oligoclase to albite in composition. Some of these plagioclase crystals show alteration to sericite in the periphery, while the core still clears preserving the twinning (Figure 4B). Biotite represents the chief mafic minerals. It occurs as subhedral to anhedral crystals. These biotite crystals show pleochroism from yellow to yellowish brown colour. Biotite crystals reach up to $1.1 \times 0.4 \mathrm{~mm}$, while the small crystals up to $0.4 \times 0.25 \mathrm{~mm}$. They are variably altered to chlorite (Figure 4C). Muscovite occurs as secondary mineral associated with biotite or as interstitial between quartz and feldspars. It is found as irregular medium flakes (Figures 4A \& B). Zircon is found as euhedral prismatic crystals included with perthite and pitchblende mineralization (Figure 4D). Fluorite occurs as anhedral to subhedral crystals displaying distinct cleavage. It varies from colors from violet to light violet (Figure 4E).

\section{Pitchblende Mineralogy}

Mineralogical and petrographical features of pitchblende mineralization and accompanied accessory minerals were determined from thin section through optical observation in transmitted and reflected light using a scanning electron microscope (SEM) with a back-scattered electron (BSE) imaging (Figures 5-7).

Pitchblende mineralization occurs as veinlets and patches filling the fractures. It is amorphous in shape, dense and bluish gray to black incolor accompanied by significant content of zircon, fluorite and lead. Zircon occurs as euhedral prismatic crystals exhibiting its characteristic interference colors and show depleted content of radioelements. Fluorite is largely present and identified by its violet colors and distinct cleavage. Lead was identified by scanning electron microscope (SEM) and microprobe analyses (Figure 7).

\section{Analytical Methods}

The pitchblende mineralization in a polished thin section prepared for the conventionalelectron microprobe analyses using a CAMECA SX-100 electron microprobe at the Centre de Recherches Petrographiqueset Geochimiques, Nancy, France. The analysis was carried out underthe following instrument operating conditions; a 15 $\mathrm{kV}$ accelerating voltage and a beam current of $10 \mathrm{nA}$. Data of microprobe analyses for the pitchblende mineralizationis listed in Table 1.

\section{Chemical Dating of Pitchblende}

Chemical U-Pb-Th dating using the electron probe
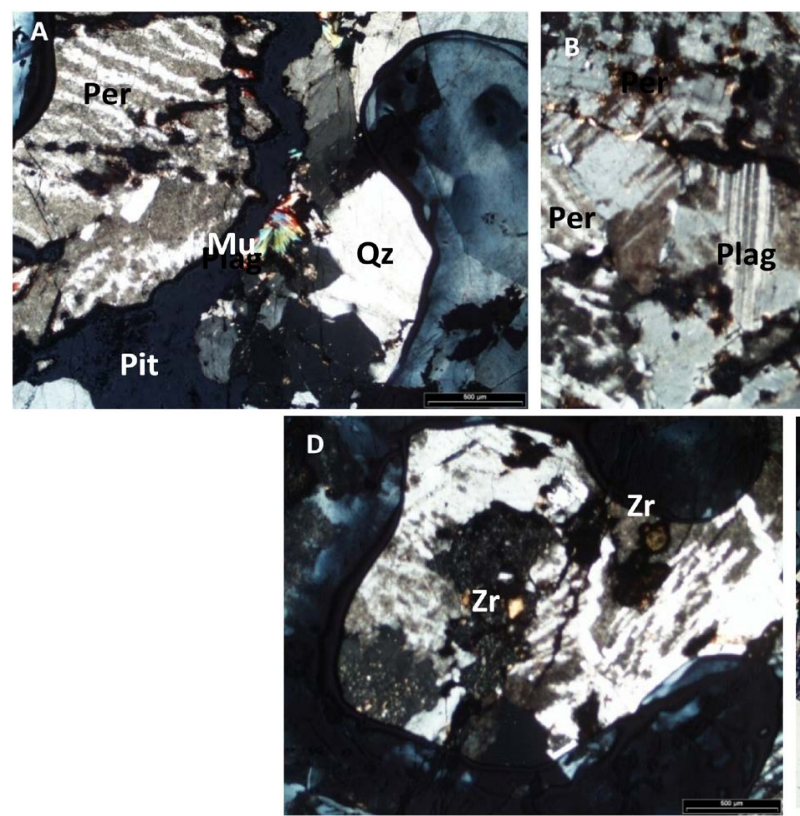
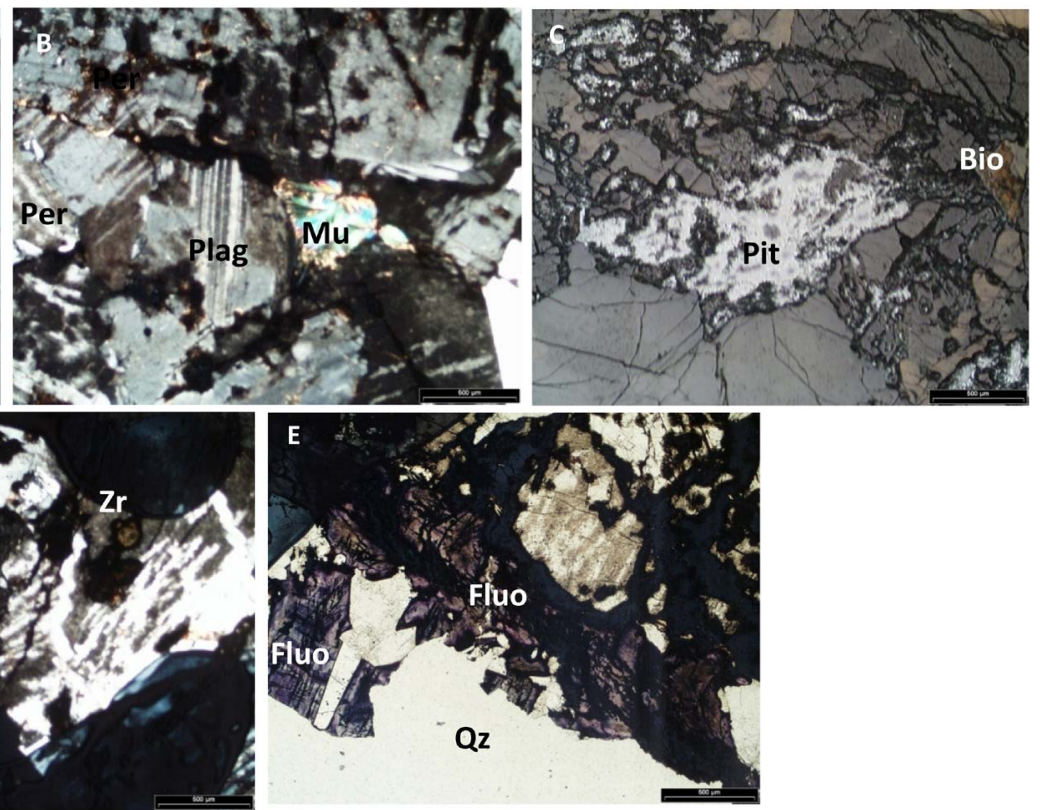

Figure 4. (A) Photomicrograph showing quartz (Qz), perthitic veinlets in perthite megacrysts (Per), and muscovite (Mu) accompanied by pitchblende (Pit). (B) Photomicrograph showing subhedral plagioclase crystal (Plag). (C) Photomicrograph showing biotite (Bio) crystals slightly altered to chlorite. (D) Photomicrograph showing euhedral prismatic zircon crystal (Zr). (E) Photomicrograph showing fluorite crystals (Fluo) displaying distinct cleavage and violet color. 

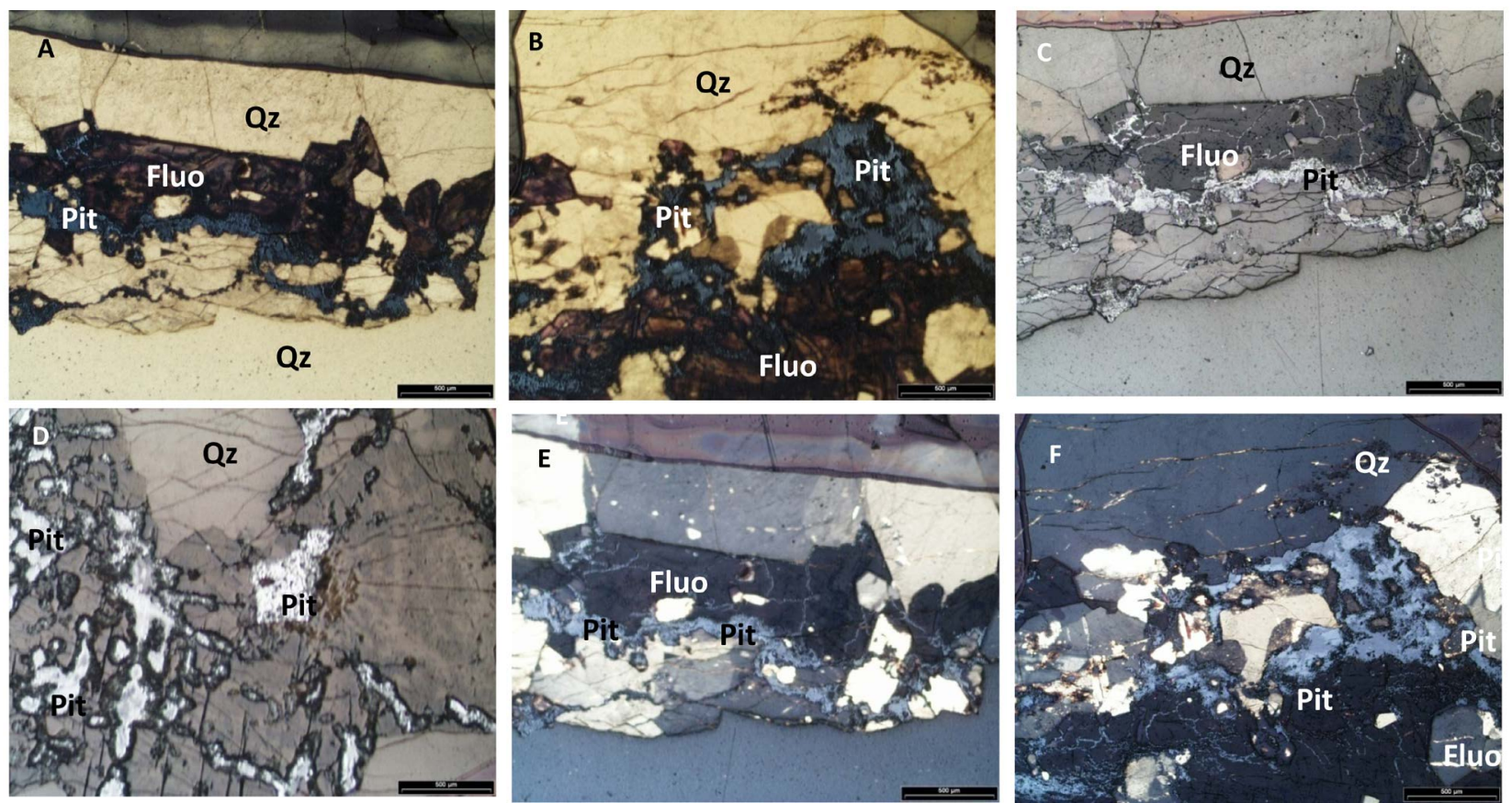

Figure 5. Photomicrograph showing pitchblende venilets and patches filling up microcracks. (A) \& (B) undernormal light, (C) \& (D) under reflecting light, (E) \& (F) under crossed polars. Pitchblende (Pit), quartz(Qz), fluorite (Fluo).
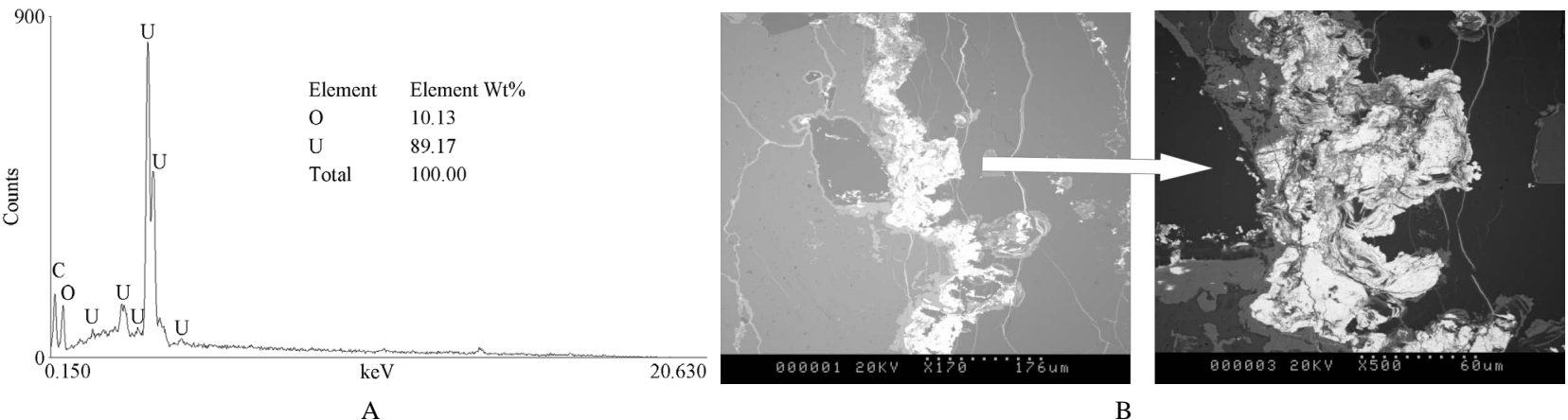

Figure 6. (A) EDX-ray pattern of pitchblende venilets. (B) Back-scattered electron imaging (BSE) of pitchblende venilets.
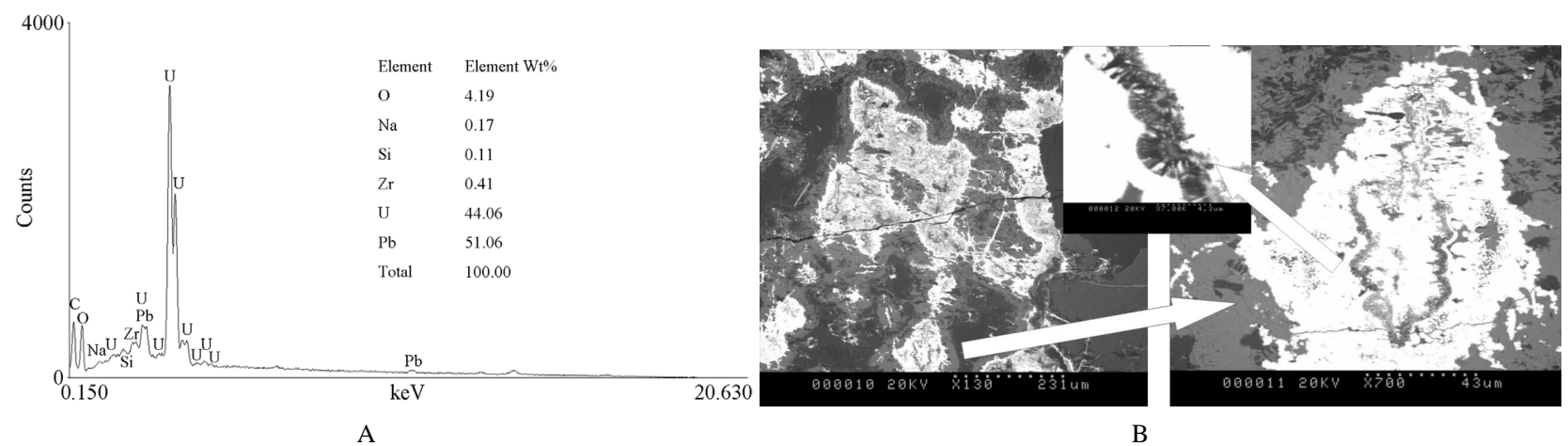

Figure 7. (A) EDX-ray pattern of pitchblende patches. (B) Back-scattered electron imaging (BSE) of pitchblende patches.

microanalyzer (EPMA) has become increasingly popular for their it's a relatively quick and low-cost method to obtain ages for detrital monazites and zircons using the electron microprobe analyses, but less accurate than iso- topes methods (e.g. Cocherie et al. [6]; Pyle et al. [22]). The principles of (EPMA) Th-U-Pb dating of monazite and zircon were first proposed by Suzuki and Adachi [23, 24], then Montel [25] systematically summarized the 
Table 1. Electron microprobe analyses (wt\%) of the pitchblende mineralization from Gabal Gattar younger granite.

\begin{tabular}{|c|c|c|c|c|c|c|c|c|c|c|c|c|c|c|c|c|c|c|c|c|c|}
\hline Number & $\mathrm{SiO}_{2}$ & $\mathbf{A l}_{2} \mathbf{O}_{3}$ & $\mathrm{TiO}_{2}$ & $\mathrm{CaO}$ & MgO & $\mathbf{P}_{2} \mathbf{O}_{5}$ & $\mathbf{L a}_{2} \mathbf{O}_{3}$ & $\mathrm{Ce}_{2} \mathrm{O}_{3}$ & $\mathrm{ThO}_{2}$ & $\mathbf{U O}_{2}$ & PbO & $\mathbf{Y}_{2} \mathbf{O}_{3}$ & $\mathrm{ZrO}_{2}$ & $\mathrm{Nd}_{2} \mathbf{O}_{3}$ & $\mathbf{G d}_{2} \mathbf{O}_{3}$ & $\mathbf{Y} \mathbf{b}_{2} \mathbf{O}_{3}$ & $\mathrm{HfO}_{2}$ & $\mathrm{Nb}_{2} \mathrm{O}_{3}$ & $\mathrm{Pr}_{2} \mathrm{O}_{3}$ & $\mathrm{SmO}_{3}$ & Total \\
\hline GT2-2-1 & 0.146 & 0 & 0.111 & 3.096 & 0.017 & 0.032 & 0 & 0 & 0 & 81.074 & 6.692 & 0.231 & 2.49 & 0.055 & 0.065 & 0.392 & 0.2 & 1.619 & 0 & 0 & 96.22 \\
\hline GT2-2-3 & 0.282 & 0 & 0.122 & 3.832 & 0.052 & 0.002 & 0.063 & 0.044 & 0.079 & 79.948 & 6.177 & 0.414 & 2.036 & 0 & 0.096 & 0.238 & 0.179 & 1.732 & 0.027 & 0.145 & 95.468 \\
\hline GT2-2-4 & 0.175 & 0 & 0 & 4.18 & 0 & 0.036 & 0 & 0 & 0 & 81.297 & 5.758 & 0.35 & 2.247 & 0 & 0 & 0.109 & 0.193 & 1.324 & 0.019 & 0.141 & 95.829 \\
\hline GT2-2-5 & 0.065 & 0.029 & 0.104 & 3.415 & 0 & 0 & 0 & 0 & 0 & 81.849 & 6.215 & 0.233 & 2.444 & 0.245 & 0 & 0.387 & 0 & 1.829 & 0 & 0 & 96.815 \\
\hline GT2-2-7 & 0.056 & 0 & 0.07 & 2.96 & 0 & 0 & 0 & 0 & 0 & 82.093 & 7.218 & 0 & 2.248 & 0.274 & 0.013 & 0.277 & 0.162 & 2.028 & 0.056 & 0.119 & 97.574 \\
\hline GT2-2-8 & 0.186 & 0 & 0.142 & 2.62 & 0 & 0.003 & 0 & 0 & 0.066 & 81.31 & 7.313 & 0.165 & 2.433 & 0.107 & 0.129 & 0 & 0 & 1.863 & 0.048 & 0 & 96.385 \\
\hline GT2-2-9 & 0.371 & 0.014 & 0.167 & 3.805 & 0.005 & 0.042 & 0 & 0.087 & 0 & 80.281 & 6.201 & 0.387 & 0.984 & 0.131 & 0.008 & 0 & 0 & 2.396 & 0.155 & 0.061 & 95.095 \\
\hline GT2-3-1 & 0 & 0 & 0.068 & 1.668 & 0 & 0 & 0 & 0 & 0 & 86.343 & 6.817 & 0 & 1.218 & 0 & 0 & 0 & 0.053 & 0.997 & 0 & 0 & 97.164 \\
\hline GT2-3-2 & 0.009 & 0 & 0.097 & 2.501 & 0 & 0.029 & 0 & 0 & 0 & 82.946 & 7.714 & 0.28 & 1.788 & 0.193 & 0 & 0.241 & 0.077 & 1.466 & 0.006 & 0.085 & 97.432 \\
\hline GT2-3-3 & 0.025 & 0 & 0.079 & 1.662 & 0.043 & 0 & 0 & 0 & 0 & 86.206 & 6.926 & 0 & 1.132 & 0.136 & 0.073 & 0.01 & 0.311 & 0.796 & 0.019 & 0.005 & 97.423 \\
\hline GT2-3-4 & 0.01 & 0 & 0.053 & 1.772 & 0.015 & 0.049 & 0 & 0 & 0 & 85.216 & 6.712 & 0.094 & 1.327 & 0 & 0 & 0 & 0 & 1.019 & 0 & 0 & 96.267 \\
\hline GT2-3-5 & 0 & 0 & 0.105 & 2.174 & 0 & 0.001 & 0 & 0 & 0 & 83.896 & 6.962 & 0.175 & 1.239 & 0.051 & 0.147 & 0 & 0 & 1.248 & 0 & 0.172 & 96.17 \\
\hline GT2-3-6 & 0.068 & 0 & 0.106 & 2.219 & 0.048 & 0 & 0 & 0 & 0 & 85.259 & 6.862 & 0.211 & 1.41 & 0.3 & 0 & 0.188 & 0.636 & 1.545 & 0.08 & 0.182 & 99.114 \\
\hline GT2-3-7 & 0.014 & 0 & 0.081 & 2.11 & 0 & 0 & 0.002 & 0 & 0.028 & 84.764 & 6.942 & 0.074 & 1.126 & 0.051 & 0 & 0.121 & 0.245 & 1.406 & 0 & 0.003 & 96.967 \\
\hline GT2-3-8 & 0.429 & 0.078 & 0.018 & 3.517 & 0 & 0 & 0.02 & 0 & 0.017 & 80.359 & 6.891 & 0.288 & 1.068 & 0.05 & 0 & 0.231 & 0.347 & 1.835 & 0 & 0 & 95.148 \\
\hline GT2-5-1 & 27.381 & 10.709 & 0.088 & 1.951 & 3.152 & 0 & 0 & 0.112 & 0 & 14.125 & 0.922 & 3.27 & 11.147 & 0.103 & 0 & 0.203 & 0.246 & 0.524 & 0.102 & 0.041 & 74.076 \\
\hline GT2-6-1 & 30.719 & 0 & 0 & 0.009 & 0 & 0 & 0 & 0 & 0.078 & 0.425 & 0 & 0.156 & 66.80 & 0.065 & 0 & 0.385 & 2.018 & 0.021 & 0 & 0.02 & 100.696 \\
\hline GT2-6-2 & 24.963 & 0.629 & 0.007 & 1.356 & 0.03 & 0 & 0 & 0 & 0.193 & 1.074 & 0.079 & 2.521 & 57.366 & 0 & 0 & 1.714 & 2.11 & 0.354 & 0 & 0.096 & 92.492 \\
\hline GT2-6-3 & 26.783 & 0.416 & 0 & 1.221 & 0.042 & 0 & 0 & 0 & 0.17 & 0.641 & 0.007 & 1.086 & 59.976 & 0.107 & 0.165 & 0.202 & 2.199 & 0 & 0 & 0 & 93.015 \\
\hline GT2-6-4 & 29.703 & 0.002 & 0.079 & 0.498 & 0.025 & 0 & 0 & 0 & 0.088 & 0.338 & 0.091 & 0 & 64.887 & 0 & 0 & 0.191 & 2.435 & 0 & 0 & 0 & 98.337 \\
\hline GT2-6-5 & 25.11 & 0.62 & 0.021 & 1.818 & 0.029 & 0 & 0 & 0 & 0.245 & 1.137 & 0.146 & 2.655 & 57.083 & 0.02 & 0.118 & 0.526 & 2.333 & 0.05 & 0 & 0 & 91.911 \\
\hline GT2-6-6 & 0 & 0 & 0.046 & 80.936 & 0 & 0.956 & 0 & 0 & 0 & 0.11 & 0.14 & 0 & 0 & 0 & 0 & 0 & 0.312 & 0.064 & 0.072 & 0 & 82.636 \\
\hline GT2-2-13 & 0.711 & 0 & 0.058 & 5.601 & 0.028 & 0.109 & 0.012 & 0.433 & 0 & 80.004 & 3.518 & 1.538 & 0 & 0.366 & 0.497 & 0 & 0 & 0.239 & 0.044 & 0 & 93.158 \\
\hline GT2-2-14 & 28.474 & 0.21 & 0.079 & 0.568 & 0.022 & 0 & 0 & 0 & 0 & 0.604 & 0.09 & 0.722 & 60.551 & 0 & 0.155 & 0.197 & 2.27 & 0 & 0.077 & 0.02 & 94.039 \\
\hline GT2-2-15 & 0.161 & 0.025 & 0.203 & 2.274 & 0.011 & 0.035 & 0.013 & 0 & 0.047 & 78.482 & 6.906 & 0.217 & 1.768 & 0 & 0 & 0.311 & 0.177 & 2.254 & 0.013 & 0.221 & 93.118 \\
\hline GT2-3-9 & 0.129 & 0 & 0.1 & 2.926 & 0.024 & 0.02 & 0 & 0 & 0 & 80.873 & 6.473 & 0.227 & 1.788 & 0.122 & 0 & 0.056 & 0.031 & 2.325 & 0 & 0 & 95.094 \\
\hline GT2-3-10 & 0.398 & 0.038 & 0.117 & 3.553 & 0.024 & 0.01 & 0 & 0.007 & 0 & 78.089 & 6.624 & 0.278 & 1.067 & 0.171 & 0.262 & 0 & 0.062 & 2.185 & 0.045 & 0.268 & 93.198 \\
\hline GT2-3-11 & 0.168 & 0 & 0.131 & 3.149 & 0.02 & 0 & 0 & 0 & 0 & 79.281 & 7.131 & 0.373 & 1.238 & 0 & 0.07 & 0 & 0.054 & 1.964 & 0 & 0.021 & 93.60 \\
\hline GT2-3-12 & 0.037 & 0 & 0.175 & 2.899 & 0.001 & 0.048 & 0 & 0 & 0 & 80.221 & 7.063 & 0.281 & 1.615 & 0 & 0 & 0.152 & 0.354 & 2.191 & 0 & 0 & 95.037 \\
\hline GT2-5-3 & 0.462 & 0.036 & 0.109 & 2.859 & 0.004 & 0.023 & 0 & 0 & 0 & 81.512 & 7.111 & 0.317 & 1.534 & 0 & 0 & 0.211 & 0.335 & 1.706 & 0.103 & 0 & 96.322 \\
\hline GT2-5-4 & 0.044 & 0 & 0.243 & 2.423 & 0.013 & 0.034 & 0 & 0 & 0 & 79.411 & 6.988 & 0.101 & 1.807 & 0.012 & 0 & 0 & 0.054 & 2.813 & 0 & 0 & 93.943 \\
\hline GT2-5-5 & 1.61 & 0.948 & 0.252 & 3.951 & 0.313 & 0.001 & 0 & 0 & 0 & 70.356 & 6.33 & 0.159 & 1.626 & 0 & 0 & 0.049 & 0.174 & 3.093 & 0.047 & 0.098 & 89.007 \\
\hline GT2-5-6 & 0.041 & 0 & 0.381 & 2.491 & 0.047 & 0 & 0 & 0 & 0 & 79.174 & 7.528 & 0.208 & 2.149 & 0 & 0 & 0.026 & 0.162 & 3.367 & 0.024 & 0.032 & 95.63 \\
\hline
\end{tabular}




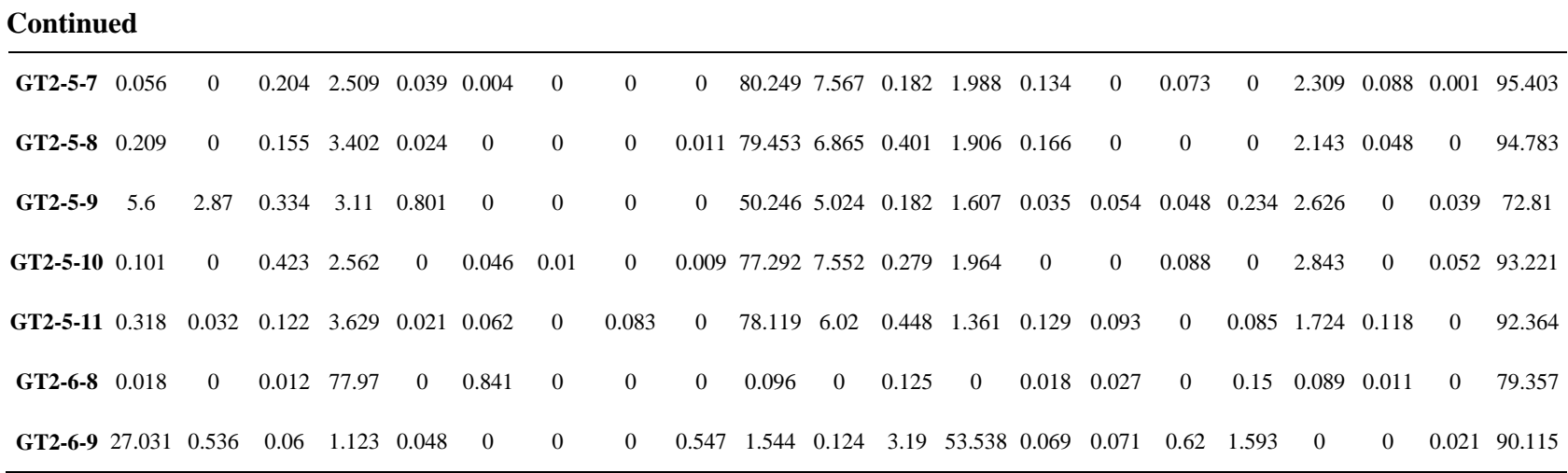

Table 2. Summary of the CHIME dating method for pitchblende mineralization from Qattar younger granite.

\begin{tabular}{|c|c|c|c|c|c|c|c|}
\hline Spot No. & $\mathrm{ThO}_{2} \mathrm{Wt} \%$ & Error Wt\% & UO2 Wt\% & Error Wt\% & PbO Wt\% & Erro Wt\% & Apparent Age (Ma) \\
\hline GT2-2-1 & 0.00 & 0.1 & 81.074 & 2.6 & 6.692 & 0.7 & 588 \\
\hline GT2-2-3 & 0.079 & 0.1 & 79.948 & 2.6 & 6.177 & 0.7 & 552 \\
\hline GT2-2-5 & 0.00 & 0.1 & 81.849 & 2.6 & 6.215 & 0.7 & 543 \\
\hline GT2-2-7 & 0.00 & 0.1 & 82.093 & 2.6 & 7.218 & 0.8 & 624 \\
\hline GT2-2-8 & 0.066 & 0.1 & 81.310 & 2.6 & 7.313 & 0.8 & 637 \\
\hline GT2-2-9 & 0.00 & 0.1 & 80.281 & 2.6 & 6.201 & 0.7 & 552 \\
\hline GT2-2-10 & 0.021 & 0.1 & 77.958 & 2.5 & 6.883 & 0.7 & 626 \\
\hline GT2-3-1 & 0.00 & 0.1 & 86.343 & 2.7 & 6.817 & 0.7 & 563 \\
\hline GT2-3-2 & 0.00 & 0.1 & 82.946 & 2.6 & 7.714 & 0.8 & 657 \\
\hline GT2-3-3 & 0.00 & 0.1 & 86.206 & 2.7 & 6.926 & 0.8 & 573 \\
\hline GT2-3-4 & 0.00 & 0.1 & 85.216 & 2.7 & 6.712 & 0.7 & 562 \\
\hline GT2-3-5 & 0.00 & 0.1 & 83.896 & 2.7 & 6.962 & 0.8 & 591 \\
\hline GT2-3-6 & 0.00 & 0.1 & 85.259 & 2.7 & 6.862 & 0.7 & 574 \\
\hline GT2-3-7 & 0.028 & 0.1 & 84.764 & 2.7 & 6.942 & 0.8 & 583 \\
\hline GT2-3-8 & 0.017 & 0.1 & 80.359 & 2.6 & 6.891 & 0.7 & 609 \\
\hline GT2-5-2 & 0.00 & 0.1 & 80.121 & 2.6 & 7.285 & 0.8 & 643 \\
\hline GT2-2-14 & 0.047 & 0.1 & 78.482 & 2.5 & 6.906 & 0.8 & 624 \\
\hline GT2-2-16 & 0.00 & 0.1 & 80.873 & 2.6 & 6.473 & 0.7 & 571 \\
\hline GT2-3-9 & 0.00 & 0.1 & 78.089 & 2.5 & 6.624 & 0.7 & 603 \\
\hline GT2-3-10 & 0.00 & 0.1 & 79.281 & 2.5 & 7.131 & 0.8 & 637 \\
\hline GT2-3-11 & 0.00 & 0.1 & 80.221 & 2.6 & 7.063 & 0.8 & 624 \\
\hline GT2-3-12 & 0.00 & 0.1 & 81.512 & 2.6 & 7.111 & 0.8 & 619 \\
\hline GT2-5-3 & 0.00 & 0.1 & 79.411 & 2.5 & 6.988 & 0.8 & 624 \\
\hline GT2-5-4 & 0.00 & 0.1 & 70.356 & 2.3 & 6.330 & 0.7 & 637 \\
\hline GT2-5-7 & 0.011 & 0.1 & 79.453 & 2.5 & 6.865 & 0.8 & 613 \\
\hline GT2-5-10 & 0.00 & 0.1 & 78.119 & 2.5 & 6.020 & 0.7 & 551 \\
\hline
\end{tabular}


method of EMPA monazite dating, and till now this method has been discussed in many articles published in China (e.g. Zhou et al. [26]; Zhang et al. [27,28]; Liu and Chen [29]; Liu et al. [30] \& 2006; Dang et al. [31]).

CHIME (chemical Th-U-total Pbisochron method) dating method, which is based on precise electron microprobe analyses of Th- and/or U-bearingminerals such as monazite, xenotime, zircon and polycrase (Suzuki and Adachi [22,23]). CHIME age calculation program is a computer program for the CHIME age calculation saves significantly the time taken to estimate the isochron age from a dataset of $\mathrm{ThO}_{2}, \mathrm{UO}_{2}$ and $\mathrm{PbO}$ or $\mathrm{Th}, \mathrm{U}$ and $\mathrm{Pb}$ analyses of Th- and/or U-bearing minerals.

CHIME age calculation for the Qattar pitchblende mineralization has been calculated using $\mathrm{U}$, Th and $\mathrm{Pb}$ content measured with an electron microprobe analyses Table 2. The data was performed using CHIME age-computer program yielded ages between 543 to $657 \mathrm{Ma}$. This is the first time that a Pan-African age (543 - $657 \mathrm{Ma}$ ) is recorded for a U-mineralization in Gabal Gattar younger granite.

\section{Results}

A total of 43 spot on the pitchblende mineralization were analyzed using electron microprobe analyses. Electron scanning microscope (ESM) and electron probe microanalyses (EPMA) revealed that this pitchblende contains significant $\mathrm{Zr}$ content reach upto $\left(66.80 \% \mathrm{ZrO}_{2}\right)$ which indicate that volcanic rocks were probably the source of this mineralization. Lead content of the pitchblende mineralization is high and with moderate volcanics (up to $7.71 \% \mathrm{PbO}$ ). In contrast, it is low in $\mathrm{ThO}_{2}, \mathrm{Y}_{2} \mathrm{O}_{3}$ and $\mathrm{REE}_{2} \mathrm{O}_{3}$. According to the calculation $\mathrm{U}-\mathrm{Pb}$ chemical ages using $\mathrm{U}$, Th and $\mathrm{Pb}$ content measured with an electron microprobe for this pitchblende yielded ages within 543 - 657 Maindicating a Pan-African age for this mineralization. This is the first time that a Pan-African age (543 to $657 \mathrm{Ma}$ ) is recorded for a U-mineralization in Gabal Gattar younger granite in the north Eastern Desert, Egypt.

\section{Conclusion}

Detailed petrographic observation, and electron scanning microscope and electron microscope analyses revealed that the pitchblende of Gabal Gattar younger granite was accompanied with high content of a number of accessory minerals such as zircon, lead and fluorite. In contrast, this pitchblende is low in $\mathrm{ThO}_{2}, \mathrm{Y}_{2} \mathrm{O}_{3}$ and $\mathrm{REE}_{2} \mathrm{O}_{3}$. High $\mathrm{Zr}$ and $\mathrm{Pb}$ content associated with pitchblende mineralization from Gattar granite indicates that the source of this mineralization derived from volcanic magma not from granitic magma. The results given in the present study, essentially by the chemical Th-U-total Pb dating, allow us to define a preliminary age lying between 543 and $657 \mathrm{Ma}$ for pitchblende mineralization of Gabal Gattar younger granite. The age obtained for pitchblende mineralization indicates that the mineralization formed in the same age of Gabal Gattar intrusion. This is the first time that a PanAfrican age (543 - $657 \mathrm{Ma}$ ) is recorded for a U-mineralization in Gabal Gattar younger granite.

\section{Acknowledgements}

We are grateful to Prof. D. Michel Cuney and his assistance Prof. D. Marc Bround, Centre de Recherchessur la del' Uranium, Nancy, France for all their help in microprobe analyses and interpreting the data.

\section{REFERENCES}

[1] M. Ghobrial and M. Lotfi, "The Geology of Gabal Qattar and GabalDokhan Areas," Paper No. 40, Eastern Desert Geological Survey, Cairo, 1967, 26p.

[2] M. A. Moussa and I. Abu El Leil, "Structural Analysis as a Guide to Mineralization Trends in the North Eastern Desert of Egypt," Annals of the Geological Survey of Egypt, Vol. 5, No. 13, 1983, pp. 271-276.

[3] R. J. Stern, D. Gottfried and C. E. Hedge, "Lat Precambrian Rifting and Crustal Evolution in North Eastern Desert of Egypt," Geology, Vol. 12, No. 3, 1984, pp. 168172.

http://dx.doi.org/10.1130/0091-7613(1984)12<168:LPRA CE $>2.0 . \mathrm{CO} ; 2$

[4] M. L. El Rakaiby and M. H. Shalaby, "Geology of Gabal Gattar batholiths, Central Eastern Desert, Egypt,” Middle East Research Center, Ain Shams University, Vol. 2, 1988, pp. 104-115.

[5] K. M. Willis, R. J. Stern and N. Clauer, "Age and Geochemistry of Lat Precambrian Sediments of Hammamt Series from the North Eastern Desert, Egypt,” Precambrian Research, Vol. 42, No. 1-2, 1988, pp. 173-187. http://dx.doi.org/10.1016/0301-9268(88)90016-2

[6] M. Y. Attawiya, "Petrochemical and Geochemical Studies of Granitic Rocks from Gabal Gattar Area, Eastern Desert, Egypt," Arab Journal of Nuclear Sciences and Applications, Cairo, Vol. 23, No. 2, 1990, pp. 13-30.

[7] T. A. Sayyah and M. Y. Attawiya, "Contribution of the Mineralogy of Uranium Occurrence of Gabal Gattar Granites, Eastern Desert, Egypt," Arab Journal of Nuclear Sciences and Applications, Cairo, Vol. 23, No. 1, 1990, pp. 171-184.

[8] A. B. Salman, I. E. El-Aassy and M. H. Shalaby, "New Occurrence of Uranium Mineralization in Gabal Gattar, Northern Eastern Desert, Egypt,” Annals of the Geological Survey of Egypt, Vol. 16, 1986-1990, pp. 31-34.

[9] A. M. El Kammar, A. E. Salman, M. H. Shalaby and A. I. Mahdy, "Geochemical and Genetical Constraints on Rare Metals Mineralization at the Central Eastern Desert of Egypt,” Geochemical Journal, Vol. 35, 2001, pp. 117135.

[10] A. El Shershaby, "Study of Radioactivity Levels in Gra- 
nite of Gable Gattar II in the North Eastern Desert of Egypt," Applied Radiation and Isotopes, Vol. 57, No. 1, 2002, pp. 131-135. http://dx.doi.org/10.1016/S0969-8043(02)00067-2

[11] M. M. El-Sayed, M. H. Shalaby and M. A. Hassanen, "Petrological and Geochemical Constraints on the Tectonomagmatic Evolution of the Late Neoproterozoicgranitoid Suites in the Gattar Area, North Eastern Desert, Egypt," Journal of Mineralogy and Geochemistry, Vol. 178, No. 3, 2003, pp. 239-275.

[12] M. F. Raslan, “Occurrence of Uraniferous Iron Grains at Gabal Gattar, El Missikat and El Erediya Granites in Eastern Desert of Egypt,” Resource Geology, Vol. 59, No. 1, 2008, pp. 99-105. http://dx.doi.org/10.1111/j.1751-3928.2008.00082.x

[13] S. A. Wasfi, E. L. Iliase and M. I. Mousa, "Discriminations of Younger Granitic Masses at Gabal Gattar Area, North Eastern Desert, Egypt, Using Remote Sensing Techniques," Egyptian Journal of Remote Sensing and Space Sciences, Vol. 12, 2009, pp. 127-148.

[14] A. Abdel Warith, M. Michalik and B. H. Ali, "Luorine Enriched Granites: Chemical Characterization and Relation to Uranium Mineralization,” Journal of Applied Sciences Research, Vol. 6, No. 4, 2010, pp. 299-323.

[15] H. M. E. Schurmann, "The Precambrian of Egypt East of River Nile Geologie en Mijnbouw,” Gravenhage, Vol. 19, No. 5, 1957, pp. 165-192.

[16] R. J. Stern and C. E. Hedge, "Geochronologic and Isotopic Constraints on Late Precambrian Crustal Evolution in the Eastern Desert of Egypt," American Journal of Science, Vol. 285, No. 2, 1985, pp. 97-127. http://dx.doi.org/10.2475/ajs.285.2.97

[17] A. H. Hashad, "Present Status of Geochronological Data on the Egyptian Basement Complex," Institute of Applied Geology, Jeddah, Bulletin, Vol. 3, No. 3, 1980, pp. 31-46.

[18] E. M. M. Moussa, "Geochronlogical Studies of Some Granitoids, Application to Geochemical Evolution and Tectonic History of the Northern Eastern Desert, Egypt,” Ph.D. Thesis, Ain Shams University, Cairo, 1998.

[19] M. E. Rose, “Geology and Uranium Mineralization of Gabal Qattar Area, North Eastern Desert, Egypt,” Ph.D. Thesis, Al-Azhar University, Cairo, 1994.

[20] E. M. El Shazaly, F. S. Bakhit and M. E. Mostafa, "Significant Structural Trends and the Relation to Radioactivity in El-Missikat Granite Pluton, Central Eastern Desert, Egypt,” In: Proceedings of the 6th International Congress for Statistics, Computer Science Social and Demographic Research, Ain Shams University, Cairo, 1981, pp. 339418.

[21] F. S. Bakhit and I. A. Kassas, "Distribution and Orientation of Radioactive Veins in the El-Erediya-El-Missikat
Area, Central Eastern Desert, Egypt,” International Journal of Remote Sensing, Vol. 10, No. 3, 1989, pp. 565-581. http://dx.doi.org/10.1080/01431168908903893

[22] J. M. Pyle, F. S. Spear, D. A. Wark, C. G. Daniel and L. C. Storm, "Contributions to Precision and Accuracy of Monazite Microprobe Ages,” American Mineralogist, Vol. 90, No. 4, 2005, pp. 547-557. http://dx.doi.org/10.2138/am.2005.1340

[23] K. Suzuki and M. Adachi, "Precambrian Provenance and Silurian Metamorphism of the Tsubonosawaparagneiss in the South Kitakamiterrane, Revealed by the Chemical Th-U-Total Pbisochron Ages of Monazite, Zircon and Xenotime,” Geochemical Journal, Vol. 25, No. 5, 1991, pp. 357-376. http://dx.doi.org/10.2343/geochemj.25.357

[24] K. Suzuki and M. Adachi, "The Chemical Th-U-Total Pbisochron Ages of Zircon and Monazite from the Grey Granite of the HidaTerrane, Japan,” The Journal of Earth Sciences, Nagoya University, Vol. 38, 1991, pp. 11-38.

[25] J. M. Montel, S. Foret, M. Veschambre, C. Nicollet and A. Provost, "Electron Microprobe Dating of Monazite," Chemical Geology, Vol. 131, No. 1-4, 1996, pp. 37-53. http://dx.doi.org/10.1016/0009-2541(96)00024-1

[26] J. X. Zhou, Z. Y. Chen and Z. Y. Rui, “Th-U-T Pb Chemical Dating of Monazite by Electron Probe,” Rock and Mineral Analysis, Vol. 21, No. 4, 2002, pp. 241-246.

[27] W. L. Zhang, R. C. Wang and R. M. Hua, "Chemical Th-U-Total Pbisochron Dating of Accessory Minerals: Principle and Application to Zircon from the Piaotang Muscovite Granite in the Xihuashan Complex, South China,” Geological Review, Vol. 49, No. 3, 2003, pp. 253-260.

[28] S. B. Zhang, Y. F. Zheng, Y. B. Wu, Z. F. Zhao, S. Gao and F. Y. Wu, "Zircon U-Pb age and Hf-O Isotope Evidence for Paleoproterozoic Metamorphic Event in South China,” Precambrian Research, Vol. 151, No. 3-4, 2006, pp. 265-288. http://dx.doi.org/10.1016/j.precamres.2006.08.009

[29] Y. L. Liu and J. F. Chen, "Chemical Method of Electronic Microprobe Dating of Monazite,” Earth Science Frontiers, Vol. 10, No. 2, 2003, pp. 394-394.

[30] S. W. Liu, G. M. Shu, Y. M. Pan and Q. N. Dang, "Electron Microprobe Dating and Metamorphic Age of Wutai Group, Wutai Mountains," Geological Journal of China Universities, Vol. 10, No. 3, 2004, pp. 356-363.

[31] Q. N. Dang, S. W. Liu, G. M. Shu and Q. G. Li, "Electron Microprobe Dating of Monazite and Its Application to the Metamorphism in the Eastern Tianshan, Xinjiang," Geological Journal of China Universities, Vol. 10, No. 4, 2004, pp. 477-487. 